\title{
Application of a Membrane-Electrode Composite Assembly to the Anodic Reaction in Brine Electrolysis
}

\author{
Hiroya YAMASHITA*, Hidemasa MATSUI $^{\dagger}$ and Katsutoshi YosHIMOTO ${ }^{\dagger}$ \\ Received October 16, 1992; Accepted January 27, 1993
}

\begin{abstract}
A membrane-electrode composite assembly with electrode catalyst on one side of the membrane was applied to the anodic reaction of brine electrolysis. The cell voltage was lower by $0.11 \mathrm{~V}$ than that of a zero gap system with an activated cathode and a $\mathrm{RuO}_{2}-$ $\mathrm{TiO}_{2}$ anode. The cell voltage, however, increased with time owing to an increase in the anode overpotential and the contact resistance between the anode catalyst and the anode current collector. Current efficiency for the production of caustic soda remained unchanged whereas the sodium chloride content of caustic soda increased to around three times higher than that obtained with the zero gap system.
\end{abstract}

\section{INTRODUCTION}

The mercury process, which is an excellent manufacturing process for producing caustic soda, was completely abolished in Japan in 1986 by administrative directions because of environmental problems. Previously, during the first conversion of the manufacturing process in 1973-1975, two thirds of the mercury cells were replaced by diaphragm cells 1 ). At present the ion exchange membrane process is gradually displacing the diaphragm process. This can be ascribed to the fact that in the membrane process caustic soda with high purity like that in the mercury process is produced, as well as to the attainment of the lowest electric power consumption by reduction of the electrolysis voltage. More reduction in the energy power consumption is, however,

Present address; Tsukuba Research Laboratory, Tokuyama Soda Co. Ltd. (40 Wadai, Tsukuba-shi, Ibaraki 300-42, Japan.)

† Tokuyama Research Laboratory, Tokuyama Soda Co. Ltd., (1-1 Mikage-cho, Tokuyama-shi, Yamaguchi 745, Japan.)

Key Words: Brine Electrolysis, Anode, MembraneElectrode Composite Assembly, Sodium Chloride Content required to stabilize the supply of caustic soda, which is an important basic chemical, irrespective of the cost of the electric power.

The ion exchange membrane cell is basically composed of a cathode evolving hydrogen, an anode which evolves chlorine and an ion exchange membrane which allows the diffusion of sodium ions but rejects the back-diffusion of cathodically-formed hydroxyl ions. Since the eutectic oxides developed by $\mathrm{H}$. Beer 2) led to an anode with low chlorine overvoltage and high chemical stability suitable for the commercial process, the main focus is now being directed to the development of a membrane with a low resistance and high transference number, and a cathode with low hydrogen overvoltage.

In the electrolysis with this process, the bubble effect at the interface between the membrane and the electrodes has been cited as a factor which causes the increase in electrolysis voltage in excess of the usual voltage drop due to the resistance of the membrane, catholyte and anolyte, and the overvoltage of the cathode and anode 3,4$)$. In order to further reduce the energy consumption, it is necessary to decrease the bubble effect. 
In this report, a membrane-electrode composite assembly was applied to the anodic reaction of brine electrolysis. The membrane-electrode composite assembly was composed of an ion exchange membrane and electrode catalyst. Such composite assemblies have been applied to fuel cells ${ }^{5)}$, water electrolysis ${ }^{5 \sim 10)}$, and electrolysis of organic compounds 11 15). The effects exerted on electrolysis voltage, caustic current efficiency and the purity of caustic soda produced were examined.

\section{EXPERIMENTAL}

A membrane-electrode composite assembly composed of an ion exchange membrane and $5 \mathrm{mg}$ $\mathrm{cm}^{-2}$ platinum or platinum (90\%) - iridium (10\%) catalyst on the anode side of the membrane was fabricated by electroless plating12,18 20). The platinum - iridium catalyst was prepared by plating platinum followed by plating iridium. The ion exchange membranes were NEOSEPTA FC001 (Tokuyama Soda Co. Ltd.). The exposed area was $0.5 \mathrm{dm}^{2}$. A platinum electrode prepared by thermal decomposition on a nickel mesh substrate covered with porous nickel was used as the activated cathode. Platinized titanium and $\mathrm{RuO}_{2}-\mathrm{TiO}_{2}$ coated titanium expanded metal were used as the current collector or as the anode in certain experiments. The temperature of the cell was maintained at $90^{\circ} \mathrm{C}$ and the current density was fixed at $30 \mathrm{~A} \mathrm{dm}^{-2}$. The concentration of the catholyte and the anolyte were maintained at $11 \mathrm{~mol} \mathrm{dm}^{-3}$ caustic soda and $3.5 \mathrm{~mol}$ $\mathrm{dm}^{-3}$ brine by supplying water and concentrated brine, respectively. Current efficiencies were obtained by measuring the volume and the concentration of caustic soda which left the cell as product. The sodium chloride content of the caustic soda produced was measured by the colorimetric method 16) using mercury thiocyanate and normalized to that of $50 \mathrm{wt} \%$ caustic soda.

\section{RESULTS AND DISCUSSION}

\subsection{Cell voltage}

Figure 1 shows the variation of cell voltage with time for a zero gap system using a $\mathrm{RuO}_{2}-$
$\mathrm{TiO}_{2}$ anode in which the distance between the membrane and electrodes is zero. This system assumed a cell voltage of $3.0 \mathrm{~V}$, in which very little change was observed. The overvoltages of the cathode and the anode used in this system were $150 \mathrm{mV}$ and $50 \mathrm{mV}$, respectively.

A system consisting of a composite assembly with Pt catalyst on the anode side of the membrane and a platinized titanium anode current collector ( $\mathrm{Ti}-\mathrm{Pt} / \mathrm{MEM}(\mathrm{Pt})$ ) and an activated cathode, was applied to brine electrolysis under the same conditions as in Fig. 1. In this system, the cell voltage was found to be reduced to $2.89 \mathrm{~V}$, which is $0.11 \mathrm{~V}$ lower than that of the zero gap system. As operating time elapsed, however, the cell voltage increased up to $3.36 \mathrm{~V}$, as shown in Fig. 2. Thus, the cell voltage of the membraneelectrode assembly system was unstable compared with that of the zero gap system.

Next, the electrolysis was carried out under the same conditions as in Fig. 2, with the exception that there was no platinum catalyst attached to the membrane. These conditions were also the same as those of the zero gap system used in Fig. 1 except that the anode was platinum coated titanium in place of $\mathrm{RuO}_{2}-\mathrm{TiO}_{2}$ coated titanium. As can be seen in Fig. 3 , the cell voltage also increased with time.

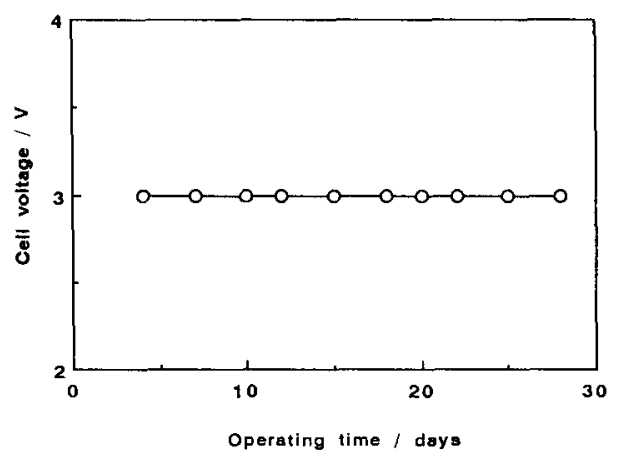

Fig. 1 Variation of cell voltage with operating time for the zero gap system with an activated cathode and $\mathrm{RuO}_{2}-\mathrm{TiO}_{2}$ anode. 
These facts imply that the platinum coated titanium exerts some influence on the cell voltage. Although the absolute values of the cell voltages shown n Figs. 2 and 3 were slightly different, there was the same tendency for the cell voltages to increase with time. Therefore, it is assumed that the increase in the cell voltage of the membrane-electrode composite assembly system is owing to the anode, that is, the overvoltage of the platinum anode increased with time.

Based on the components of the cell voltage obtained from the zero gap system using the same membrane and cathode ${ }^{3,4}$ ), the details of the cell

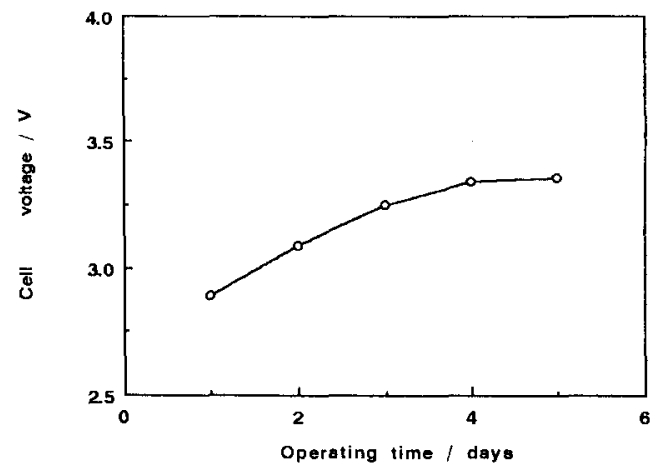

Fig. 2 Variation of cell voltage with operating time for a membrane-electrode composite assembly system with a platinum-coated titanium current collector.

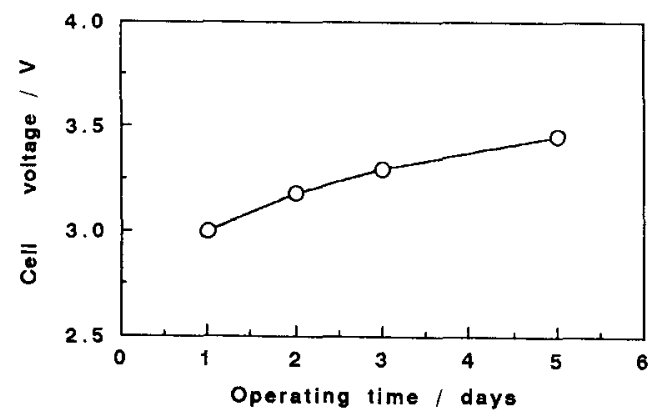

Fig. 3 Variation of cell voltage with operating time for the zero gap system with an activated cathode and a platinum-coated titanium anode. voltage of the membrane-electrode composite assembly system were derived, and are shown in Table 1. The voltage drop due to the sum of the anode overvoltage, the contact resistance between the anode current collector and anode catalyst, and the anode bubble effect was reduced to from $0.19 \mathrm{~V}$ to $0.08 \mathrm{~V}$. This reduction is considered to be the result of a decrease in the anode bubble effect. The overvoltage of the anode catalyst attached onto the membrane was not measured separately. Even if the overvoltage of the anode catalyst and the voltage drop due to the contact resistance between the anode catalyst and the anode current collector are zero in the membrane-electrode composite assembly system, the reduction in the anode bubble effect is still 60 $\mathrm{mV}$. Thus, although the voltage drop owing to the anode overvoltage and the contact resistance

Table 1 Components of cell voltage for zero gap system and membrane-electrode composite assembly (MECA) system.

\begin{tabular}{|c|c|c|}
\hline $\begin{array}{ll}\text { System } \\
\text { Component }\end{array}$ & $\begin{array}{l}\text { ZERO GAP } \\
(\text { Anode: } \\
\left.\mathrm{RuO}_{2}-\mathrm{TiO}_{2}\right)\end{array}$ & $\begin{array}{c}\text { MECA } \\
\text { (initial) }\end{array}$ \\
\hline $\begin{array}{l}\text { Decomposition } \\
\text { voltage }\end{array}$ & $2.17 \mathrm{~V}$ & $2.17 \mathrm{~V}$ \\
\hline Membrane potential & $0.09 \mathrm{~V}$ & $0.09 \mathrm{~V}$ \\
\hline $\begin{array}{l}\text { Membrane } \\
\text { resistance }\end{array}$ & $0.24 \mathrm{~V}$ & $0.24 \mathrm{~V}$ \\
\hline $\begin{array}{l}\text { Anode overvoltage } \\
\text { Contact resistance }\end{array}$ & $0.05 \mathrm{~V}$ & $0.08 \mathrm{~V}$ \\
\hline Anode bubble effect & $0.14 \mathrm{~V}$ & \\
\hline $\begin{array}{l}\text { Cathode } \\
\text { overvoltage }\end{array}$ & $0.15 \mathrm{~V}$ & $0.15 \mathrm{~V}$ \\
\hline $\begin{array}{l}\text { Cathode bubble } \\
\text { effect }\end{array}$ & $0.11 \mathrm{~V}$ & $0.11 \mathrm{~V}$ \\
\hline $\begin{array}{l}\text { Electrolyte } \\
\text { resistance }\end{array}$ & $\mathrm{OV}$ & $0 \mathrm{~V}$ \\
\hline $\begin{array}{l}\text { Electron conductor } \\
\text { resistance }\end{array}$ & $0.05 \mathrm{~V}$ & $0.05 \mathrm{~V}$ \\
\hline Total & $3.00 \mathrm{~V}$ & $2.89 \mathrm{~V}$ \\
\hline
\end{tabular}

Electrolysis conditions

Temperature: $90^{\circ} \mathrm{C}$

Current density: $30 \mathrm{~A} \mathrm{dm}^{-2}$

Anolyte: $3.5 \mathrm{~mol} \mathrm{dm}^{-3} \mathrm{NaCl}$

Catholyte: $11 \mathrm{~mol} \mathrm{dm}^{-3} \mathrm{NaOH}$ 
is not actually zero, it can be concluded that at least $60 \mathrm{mV}$ of the anode bubble effect of $140 \mathrm{mV}$ was saved.

As electrolysis continued, however, the cell voltage increased up to $3.36 \mathrm{~V}$, which is considered to have resulted from the increase in the sum of the anode overvoltage and the contact resistance between the anode current collector and anode catalyst, which became $0.55 \mathrm{~V}$, as shown in Table 2. It is said that the chlorine overvoltage of platinum increases drastically with operating time as a result of the oxide formation on the surface of platinum regardless of its low overvoltage during the initial stages of electrolysis 21 ). Therefore, the anode overvoltage is thought to account for most of the increase in the cell voltage of the membrane-electrode composite assembly system.

Since the platinum catalyst attached to the membrane was considered to have exerted some influence, the platinum catalyst was replaced by platinum-iridium catalyst of which chlorine overvoltage seemed to be lower than that of platinum. The results are shown in Fig. 4. The

Table 2 Components of cell voltage for membrane-electrode composite assembly (MECA) system after 4 days.

\begin{tabular}{|c|c|}
\hline System & MECA \\
\hline Decomposition voltage & $2.17 \mathrm{~V}$ \\
\hline Membrane potential & $0.09 \mathrm{~V}$ \\
\hline Membrane resistance & $0.24 \mathrm{~V}$ \\
\hline Anode overvoltage and contact resistance & \multirow{2}{*}{$0.55 \mathrm{~V}$} \\
\hline Anode bubble effect & \\
\hline Cathode overvoltage & $0.15 \mathrm{~V}$ \\
\hline Cathode bubble effect & $0.11 \mathrm{~V}$ \\
\hline Electrolyte resistance & $0 \mathrm{~V}$ \\
\hline Electron conductor resistance & $0.05 \mathrm{~V}$ \\
\hline Total & $\overline{3.36 \mathrm{~V}}$ \\
\hline
\end{tabular}

Electrolysis conditions

Temperature: $90^{\circ} \mathrm{C}$

Current density: $30 \mathrm{~A} \mathrm{dm}^{-2}$

Anolyte: $3.5 \mathrm{~mol} \mathrm{dm}^{-3} \mathrm{NaCl}$

Catholyte: $11 \mathrm{~mol} \mathrm{dm}^{-3} \mathrm{NaOH}$ cell voltage also increased, although the rate of increase was reduced to some extent. This increase in cell voltage can be also explained by the increase in the sum of the anode overvoltage and the contact resistance between the anode current collector and the anode catalyst. The platinum-iridium catalyst used in this study was not an alloy, which may have been one of the reasons for the increase in cell voltage. However, the details of this catalyst were not examined specifically, and further quantitative study is necessary.

Thus, although the cell voltage of the composite assembly system was $0.11 \mathrm{~V}$ lower than that of the zero gap system during the initial stages of electrolysis, the increase in cell voltage with time could not be suppressed. These facts imply that it is necessary to deposit a catalyst with properties similar to $\mathrm{RuO}_{2}-\mathrm{TiO}_{2}$, i.e., low chlorine overvoltage and high stability,onto the ion exchange membrane in order to improve the performance of the composite assembly system.

\section{2 $\mathrm{NaCl}$ content of caustic soda}

One of the advantages in the membrane process is that caustic soda with higher purity can be produced than in the diaphragm proces. Therefore, it is important to examine the purity of caustic soda obtained by the membraneelectrode composite assembly process. Table 3 shows the sodium chloride content of caustic soda when the various electrodes described in section 3.1 were used. It can be seen that the sodium

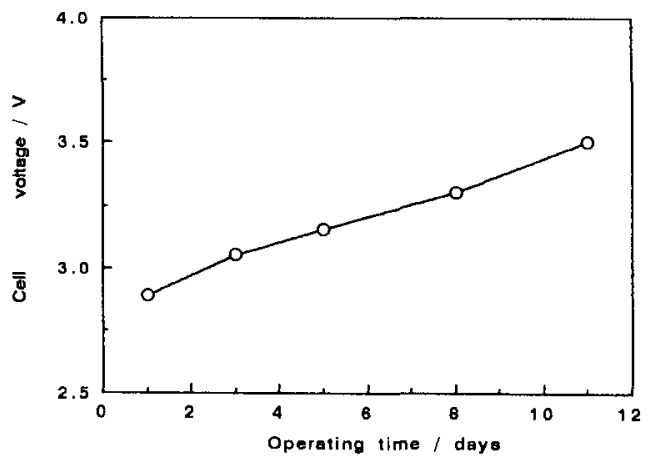

Fig. 4 Variation of cell voltage with operating time for a membrane-electrode( $\mathrm{Pt}-\mathrm{lr}$ ) composite assembly system with a platinum-coated titanium current collector. 
chloride content of caustic soda normalized to that of 50 wt\% caustic soda increased up to 150 ppm for the composite assembly method using a platinized titanium anode current collector, whereas the sodium chloride content was $40 \mathrm{ppm}$ for the zero gap method regardless of the anode material. It is worth noting that the application of the composite assembly to the anodic reaction of brine electrolysis caused the increase in the sodium chloride content of caustic soda produced. On the other hand, for the composite assembly system using a $\mathrm{RuO}_{2}-\mathrm{TiO}_{2}$ anode current collector in place of the platinized titanium anode current collector, it turned out that the sodium chloride content decreased to a value as low as that of the zero gap system.

These facts suggest that the increase in the sodium chloride content of caustic soda with the membrane - electrode composite assembly system is not caused by deterioration of the membrane by the attachment of catalyst. It seems that the sodium chloride content of caustic soda is closely related to the nature of the anode current collector. However, the $\mathrm{RuO}_{2}-\mathrm{TiO}_{2}$ anode current collector and the platinum coated titanium current collector used in this study were little different from each other in shape and size. Therefore, it is assumed that the chlorine overvoltage of the anode current collector has some influence on the sodium chloride content of caustic soda. Taking the chlorine overvoltage of the materials into consideration, the anodic reaction of chlorine evolution can be thought to occur at the $\mathrm{RuO}_{2}-\mathrm{TiO}_{2}$

Table 3 Dependence of $\mathrm{NaCl}$ contents of caustic soda on electrolysis system.

\begin{tabular}{|l|c|}
\hline \multicolumn{1}{|c|}{ Electrolysis system } & $\begin{array}{c}\mathrm{NaCl} \\
\text { contents/ppm } \\
(50 \% \mathrm{NaOH})\end{array}$ \\
\hline Zero Gap (Anode: $\mathrm{RuO}_{2}-\mathrm{TiO}_{2}$ ) & 40 \\
\hline Zero Gap (Anode: $\mathrm{Pt})$ & 40 \\
\hline $\begin{array}{l}\text { Membrane-electrode composite } \\
\text { assembly (Pt current collector) }\end{array}$ & 150 \\
\hline $\begin{array}{l}\text { Membrane-electrode composite } \\
\text { assembly (RuO } \\
\text { collector) }\end{array}$ & 60 \\
\hline
\end{tabular}

current collector for the membrane-electrode composite assembly system with a $\mathrm{RuO}_{2}-\mathrm{TiO}_{2}$ anode current collector because the overvoltage of $\mathrm{RuO}_{2}-\mathrm{TiO}_{2}$ is lower than that of platinum. Even if the electrode potential of the anode catalyst is equal to that of the anode current collector, the anodic reaction of chlorine evolution is thought to proceed at the site for which the chlorine overvoltage is lower. Accordingly, it is thought the sodium chloride content of caustic soda depends on the site at which the anodic reaction of chlorine evolution occurs. Then, the decrease in the sodium chloride content of caustic soda with the membrane-electrode assembly system using the $\mathrm{RuO}_{2}-\mathrm{TiO}_{2}$ current collector can be explained by the occurrence of the anodic reaction at the current collector. In turn, the increase in the sodium chloride content can be considered to be caused by the occurrence of the anodic reaction at the catalyst attached to the ion exchange membrane and not by deterioration of the membrane. More specifically, the chlorine gas evolved at the interface of the anode catalyst and the membrane permeated through the membrane to the catholyte, leading to the increase of the sodium chloride content of caustic soda as a result of the reduction of sodium hypochlorite, which is the reaction product of chlorine and caustic soda. It has been reported that chlorine gas permeates through a membrane from the anode side to the cathode side in hydrochloric electrolysis with the membraneelectrode composite assembly system 17 ). It appeared to be more difficult for the chlorine gas evolved at the catalyst deposited onto the membrane to move in the direction of the anode compartment than the chlorine gas evolved at the anode of the zero gap system. This was confirmed by the fact that the sodium chloride content increased more when the electrode catalyst penetrated deeply into the membrane.

Disassembly of the membrane-electrode composite assembly cell after continuous electrolysis for more than 5 days revealed that there were many blisters over the entire surface of the membrane. This is thought to have resulted from depletion of sodium chloride at the interface 
between the anode catalyst and the membrane, because blisters were also observed on membrane surfaces with the zero gap system at spots where insufficient brine was supplied. This depletion of sodium chloride at the interface between the anode catalyst and the membrane is considered to be caused by the suppression of the supply of the sodium chloride solution by the chlorine gas evolved at the anode catalyst which covers the surface of the ion exchange membrane. The increase in the migration of hydration water with sodium ions across the membrane and the local change in the $\mathrm{pH}$ of the anolyte at the interface between the membrane and the anode catalyst can be thought of as one of the immediate causes of the blister formation. However, the details are unknown. The blisters formed on the membrane are thought to cause a small increase in the sodium chloride content of the caustic soda produced. However, the sodium chloride content of caustic soda decreased to a value of less than 100 ppm when the membrane-electrode composite assembly, which had blisters, was applied in the zero gap system. Therefore, it is concluded that the blisters formed on the surface of the membrane are not a major cause of the increase in the sodium chloride content with the membraneelectrode composite assembly system.

The purity of caustic soda produced is an important problem compared with hydrochloric electrolysis in which there is no change in the purity of gas though a small decrease in current efficiency is observed 17). However, since the quantitative relation between the quantity of electricity and the volume of gas permeating through the membrane was not obtained, further investigation is required in the case of brine electrolysis.

\subsection{Current efficiency}

In addition to the purity of caustic soda and the cell voltage, caustic current efficiency is also an important factor in brine electrolysis. Table 4 shows the current efficiency for the production of caustic soda when the various electrodes described in section 3.1 were applied. As can be seen in Table 4, there is no difference in current efficiency owing to the variation of electrolysis conditions. These results indicate that the application of a membrane-electrode composite assembly to the anodic reaction exerts little influence on caustic current efficiency.

Table 4 Dependence of current efficiency on electrolysis system

\begin{tabular}{|l|c|c|}
\hline Electrolysis system & $\begin{array}{c}\text { Current } \\
\text { efficiency / \% } \\
\text { (after } \\
\text { 3 days) }\end{array}$ & $\begin{array}{c}\text { Current } \\
\text { efficiency /\% } \\
\text { (after } \\
\text { 5 days) }\end{array}$ \\
\hline $\begin{array}{l}\text { Zero Gap (Anode: } \\
\left.\mathrm{RuO}_{2} \text {-TiO }\right)\end{array}$ & 95 & 95 \\
\hline Zero Gap (Anode: Pt) & 95 & 95 \\
\hline $\begin{array}{l}\text { Membrane- } \\
\text { electrode composite } \\
\text { assembly (current } \\
\text { collector: Pt) }\end{array}$ & 95 & 95 \\
\hline $\begin{array}{l}\text { Membrane-elec- } \\
\text { trode composite } \\
\text { assembly (current } \\
\text { collector: RuO } \\
\text { TiO }-\end{array}$ & 95 & 95 \\
\hline
\end{tabular}

\section{CONCLUSION}

A membrane-electrode composite assembly was applied to the anodic reaction of brine electrolysis. The cell voltage was lower than that of the zero gap system with an activated cathode and a $\mathrm{RuO}_{2}-\mathrm{TiO}_{2}$ anode by $0.11 \mathrm{~V}$. The cell voltage, however, increased with time owing to the increase in anode overpotential and the contact resistance between the anode catalyst and the anode current collector.

Application of a composite assembly did not affect the caustic current efficiency, whereas the sodium chloride content of caustic soda was about three times higher than that with the zero gap system. Blisters were found on the membrane surface after electrolysis by the membraneelectrode composite assembly method, suggesting that there was a depletion layer of brine at the interface of the membrane and the electrode catalyst attached to the membrane. 


\section{REFERENCES}

1) Chloro-Alkali Industrial Society of Japan, Soda to Enso, 32, 4 (1981).

2) Henry Beer, Nippon Tokkyo Koho, Showa 4621884 (1971).

3) K. Yoshimoto, S. Matsuura and S. Akiyama, The proceedings of 7 th symposium of chloro-alkali technology in Kyoto, p. 89 (1983).

4) N. Okada, K. Yoshimoto and S. Akiyama, The Proceeding of 8 th symposium of chloro-alkali technology in Kyoto, p. 5 (1984)

5) A. B. LaConti, Proceeding of the Oronzio De Nora Symp. (1979).

6) L. J. Nutall, International J. of Hydrogen Energy, 2, 395 (1977).

7) A. B. LaConti, A. R. Fragala and J. R. Boyack, Proceedings of the Symposium on Electrode Materials and Process for Energy Conversion and Storage, p. 354 (1977).

8) H. Takenaka, E. Torikai, Y. Kawami and N. Wakabayashi, 46th Annual meeting of the Electrochemical Society of Japan, Abstr., p. 218 (1979).

9) H. Takenaka, E. Torikai, Y. Kawami and N. Wakabayashi, The Proceeding of 3rd symposium of Chloro-Alkali technology in Kyoto, p. 51 (1979).

10) H. Takenaka, E. Torikai, Y. Kawami and T. Sakai, The Proceeding of 6 th symposium of
Chloro-Alkali technology in Kyoto, p. 13 (1982).

11) S. Yoshizawa, Z. Ogumi and K. Nishio, 46th Annual meeting of the Electrochemical Society of Japan, Abstr., p. 127 (1979).

12) Z. Ogumi, K. Nishio, and S. Yoshizawa, Denki Kagaku, 49, 212 (1981).

13) Z. Ogumi, K. Nishio, and S. Yoshizawa, Electrochim. Acta, 26, 1779 (1981).

14) Z. Ogumi, H. Yamashita, K. Nishio, Z. Takehara and S. Yoshizawa, Electrochim. Acta, 28, 1687 (1983).

15) Z. Ogumi, H. Yamashita, K. Nishio, Z. Takehara and S. Yoshizawa, Denki Kagaku, 52, 180 (1983).

16) Jikken Kagaku Koza (Ed. Chem. Soc. Jpn.) Maruzen, vol. 9, p. 241 (1976).

17) I. Uehara, Y. Kawami, N. Wakabayashi, M. Motone and H. Takenaka, Denki Kagaku, 58, 459 (1990).

18) H. Takenaka and E. Torikai, Nippon Tokkyo Koho, Showa 55-38934 (1980).

19) I. Uehara, Y. Kawami, N. Wakabayashi, M. Motone and H. Takenaka, Denki Kagaku, 58, 360 (1990).

20 H. Takenaka, E. Torikai, Y. Kawami, N. Wakabayashi and T. Sakai, Denki Kagaku, 53, 261 (1985).

21) N. Kameyama, Denkikagaku no Riron oyobi Ouyou part I (Maruzen), p. 393 (1963). 